\title{
VIEWPOINTS
}

\section{State-Building Dilemmas After the Arab Spring}

\author{
Tengku Ahmad Hazri*
}

The alarming state of West Asia and North Africa (WANA) today reverses conventional wisdom regarding constitutionalism. For long the Holy Grail of constitutional reform was on finding the best way to limit government authority. Yet the sheer chaos and instability of Middle East regimes now leads many to wonder if indeed the real problem is not the lack of functioning statehood to start with. How could one "limit" state authority when the personal dictatorships across the land hardly qualify as functioning states at all? That the states disintegrated into chaos after the fall of the rulers - evident especially in the case of Libyaprovokes the question whether the so-called state institutions were not merely extended shadows of one man, whose downfall naturally brought with it the end of the entire political infrastructure.

The political crises that now attend the region are not merely peripheral but they challenge the whole map of the Middle East, and question the very sobriety of the imposed territorial settlement that has guided —or perhaps, misguidedforeign policies towards WANA since the 1916 Sykes-Picot agreement divided territories of the ailing Ottoman Empire into Western spheres of influence.

Amidst such debates, old grievances long since brewing in Islamic intellectual circles have now resurfaced: the long censure of the Westphalian nation-state system by leading ideologues and intellectuals from Hassan al-Banna, Sayyid Qutb and Abu'l A'la Maududi to Ayatollah Khomeini. The limits of this model are now evident in the fragmentation of states after the Arab Spring such as the move towards a separate homeland, Kurdistan for the Kurds carved out of Iraq.

These critiques have acquired renewed respectability in the light of developments in Europe itself-Scotland's failed bit to secede from the UK, Catalonia's call for independence from Spain, the contested status of Crimea between Russia and Ukraine, and more generally, the never-ending crisis in the European Union - all of which like the falling stones that foreshadow an avalanche. Indeed, there is growing recognition even in Europe itself that the Westphalian system has reached its limit. The rise of legal pluralism further challenges the jural integrity of nation-state based on legal uniformity, echoed succinctly by the Austrian jurist Hans Kelsen who conceived the "state" as identical with its legal order. 
Notwithstanding these developments, constitutional reforms in the Middle East have only the Westphalian model as the sole template on offer. When viewed in the light of global transition towards a post-Westphalian order, the imposition of such framework in the nascent post-dictatorship states of WANA can be construed either condescendingly as naive neglect of global trends or cynically as a deliberate attempt to keep these states "lagging behind" as they struggle to accommodate the very system which the "advanced" nations themselves have rejected in search of what is perceived to be a better system. The supposed "better" system sought for by the Western states is one that fosters greater cooperation between states underpinned by respect for international law and international standards of human rights. These can be interpreted as gradual moves towards the construction of a moral core around which international relations revolve, marking a retreat from the amorality that ostensibly necessitated the system to start with.

As Henry Kissinger concedes in his recent work, World Order, a primary weakness of the Westphalian system is its value-neutrality, its conscious moral agnosticism in favor of procedural claims on territorial integrity, sovereignty of states and non-interference in domestic affairs among states. Consequently, it gives no sense of direction and is incapable of generating legitimacy. The void which the system creates thus now came to be filled by extremist ideologies and movements promising certainty and direction — indeed, even martyrdom and salvation.

Curiously enough, these concerns mirror those of many Muslim intellectuals who charged the nation-state as the very culprit responsible for the deplorable plight of Muslim minorities in different parts of the world from Palestine in the Middle East, Chechnya in Central Asia, and Xinjiang in China to southern Thailand and Myanmar. It is seen as symptomatic of the failure of the system itself. This is exacerbated by failed state-building projects in the Muslim world such as Iraq and Libya, all of which have degenerated into failed states. Thus these critics argue for a system transcending the (real or perceived) divisive nature of the current arrangement. That the global trends are now moving in the direction envisaged by these critics, i.e. away from the nation-state, thus can easily be read with a triumphalist tenor, seeing in them an emphatic vindication if not solid confirmation of the very thesis they have been advocating all along.

No doubt even within the current framework, attempts have been made to advance the post-Westphalian agenda. In fact, Article 11 of Iran's constitution, under direct inspiration from the Holy Qur'an (Surah al-Anbiya' 21:92), explicitly proclaims the entire Muslim world as a "single nation" and obligates the Islamic Republic to secure the "unity of all Muslim peoples". The nationstate's merits must thus never be underestimated. Among others, hitherto 
unimagined fraternities have been forged in its name, suggesting its viability as the starting point to transcend itself. For a start, this effort must begin even within the nation-state. Conventional political wisdom often dictates the exclusion of religion from the public sphere to make way for what has been called 'public reason'. But in a world of instant communication, ideas that find no currency at home may be swiftly smuggled for consumption in the 'black market' abroad, among dissidents ready to countenance violence. The state's attempt to suppress ideas will then backfire as its policies aimed at promoting national unity turned out to be productive of homegrown detractors seeking political goals outside the legitimate boundaries of the public sphere which have been denied to them.

Thus states which have nurtured a healthy pluralist and multicultural tradition must continue to allow the different communities to flourish with their civilisational heritage intact, and not forsake the latter to be replaced by a vaguely defined "national identity". Instead, they should mutually reinforce and enrich one another. Religious discourses must thus actively pervade the public domain. Should such a move generate conflicts in the initial phases, these must be seen as but the birth-pangs of a more creative and better system. The hour before dawn, after all, is always bleak.

\section{Notes}

* Tengku Ahmad Hazri is Research Fellow at IAIS Malaysia. He can be contacted at ahmhazri@iais.org.my. 